\title{
Effect of Malted Sorghum on Quality Characteristics of Wheat-Sorghum-Soybean Flour for Potential Use in Confectionaries
}

\author{
Opeyemi O. Aluge, Stephen A. Akinola, Oluwatooyin F. Osundahunsi \\ Department of Food Science and Technology, Federal University of Technology, Akure, Nigeria \\ Email: akinolastephen3@gmail.com
}

How to cite this paper: Aluge, O.O., Akinola, S.A. and Osundahunsi, O.F. (2016) Effect of Malted Sorghum on Quality Characteristics of Wheat-Sorghum-Soybean Flour for Potential Use in Confectionaries. Food and Nutrition Sciences, 7, 1241-1252. http://dx.doi.org/10.4236/fns.2016.713114

Received: September 28, 2016 Accepted: November 6, 2016

Published: November 9, 2016

Copyright $\odot 2016$ by authors and Scientific Research Publishing Inc. This work is licensed under the Creative Commons Attribution International License (CC BY 4.0).

http://creativecommons.org/licenses/by/4.0/ (c) (i) Open Access

\begin{abstract}
Effect of malting on quality characteristics of wheat-malted sorghum-soybean composite flour was investigated. Composite flours from wheat, malted sorghum and soybean flour were made in the ratios: $85 \%: 10 \%: 5 \%$ (WSS1); 80\%:15\%:5\% (WSS2) and 75\%:20\%:5\% (WSS3). Whole sorghum flour (WSF) 100\% served as control. Protein content of the composite flours ranged from $11.78 \%$ to $11.98 \%$. Malted sorghum improved the protein content of the flour at substitution level greater than $10 \%$. At $20 \%$ substitution with malted sorghum, crude fibre $(1.98 \%)$ and total ash contents (3.96\%) increased significantly suggesting a good source of minerals. Bulk density $(0.86 \mathrm{~g} / \mathrm{ml})$, Water absorption capacity $(1.67 \%)$ of the composite flours were not significantly different ( $\mathrm{p} \leq 0.05)$, but different from control $(1.07 \%)$. Oil absorption ranged from $0.95 \%$ to $1.68 \%$, and swelling capacity from 3.33 to $9.17 \mathrm{ml} / \mathrm{g}$. Least gelation concentration ranged from $4.67 \%$ to $9.33 \%$. Cyanide content $(1.38 \mathrm{mg} / \mathrm{g})$ was lowest in WSF. At $15 \%$ malted sorghum substitution phytate $(1.14 \mathrm{mg} / \mathrm{g})$ was lowest. Final viscosity ranged from 243.0 to $297.50 \mathrm{RVU}$, set back from 34.83 to $75.01 \mathrm{RVU}$, pasting temperature from $72.77^{\circ} \mathrm{C}$ to $80.49^{\circ} \mathrm{C}$, and peak time from 4.10 to $5.46 \mathrm{~min}$ increased with increasing level of substitution. Peak viscosity (281.00 - 434.92 RVU), holding strength (164.41 - $221.06 \mathrm{RVU})$ and breakdown (59.25 - 221. $06 \mathrm{RVU})$ decreased with increase in substitution. Malting improves the nutrient quality of wheat-malted sorghum-soybean composite flour. Composite flour with up to $20 \%$ malted sorghum substitution could find application in confectionary industries.
\end{abstract}

\section{Keywords}

Malting, Sorghum, Soybean, Composite Flour, Quality

\section{Introduction}

The progressive increase in the consumption of baked products in Nigeria makes com- 
posite flour technology of choice in conserving losses due to foreign exchange. Wheat flour (Triticum aestivum) is a flour of choice in confectionary industries due to the component gluten. Gluten (prolamin and glutenins) is responsible for the desirable rheological properties in confectionaries. Wheat is not typical to West Africa; it is imported to meet the ever increasing demands. This in turns weakens the foreign reserves of many countries when alternatives exist. Composite flour technology is a means to reduce the menace of the over dependence on wheat flour in confectionary industries. Composite flour refers to wheat that has been diluted with non-wheat materials like cassava, maize and soybean [1]. In recent times, composite flours includes mixture of flours from tubers rich in starch (e.g. cassava, potatoes, yam) and/or protein-rich flours (soybean, ground nut) and/or cereals (maize, rice, millet, sorghum) with or without wheat flour [2]. Composite flour technology encourages: the utilisation of less known, underutilized crops, better supply of proteins for human nutrition, enhancement of domestic agriculture and rural income [3]. Flours from gluten free crops have rheological properties that are useful during dough making [4].

Sorghum (Sorghum bicolor) is a gluten-free cereal grown in many African countries primarily as food crop with less than $5 \%$ of the annual production commercially processed by the industry [5]. Sorghum grain ranks third among the domesticated cereals for human consumption and forms a major staple in many African countries, India and China [6] [7]. It is the grain of choice in brewing African traditional beers. Sorghum is composed of antinutrients which can inhibit the absorption of essential minerals and proteins in the body. Processing treatments such as soaking, malting, fermentation have been reported to inhibit antinutrients in cereals, legumes, roots and tubers [8]. Efforts are currently geared towards enhancing the protein content of composite flours through supplementation with arrays of legumes.

Soybean (Glycine max) belongs to the family leguminosae and sub-family papillionnideae. It is a remarkable cheap source of plant protein for both animals and man and a leading source of edible oils and fats [9] [10]. Soybean is nutritionally dense and rich in phytochemicals, copper, zinc and manganese [11]. Daily consumption of soybean (30 and $50 \mathrm{~g}$ ) can substitute for an equal amount of animal-based proteins, resulting in a considerable reduction in harmful low density cholesterol with an increase in the beneficial [12]. According to [13] mixing of legumes with cereals can improve overall nutrition.

In the last two and half decades, considerable efforts have been made on the use of composite flour for bread and baked products [7]. Bread production has been reported from non-gluten cereals such as rye, maize [14], barley and oats, roots like cassava as composite with wheat flour [15]. According to the report of [16] flour from indigenous crops can give a quality and acceptable final products if flours are added in proportions that will not affect its rheological properties negatively. To this end, attempts at partial substitution of wheat flour with Maize, cocoyam, bread fruit and sorghum and high protein seeds for use in confectionary industries have been investigated [17] [18]. The potentials of wheat-based composite flours have been investigated with promising re- 
sults showing that partial substitution may be possible [14] [19] [18]. Although, there exist substantial amount of available composite flour technology for bread production, such breads still require at least 70 percent wheat flour to obtain good products [20]. Hence, this study investigated the effect of malted sorghum substitution on quality characteristics of composite flours from wheat, sorghum and soybean for potential use in confectionaries.

\section{Materials and Methods}

Whole wheat (T. aestivum), white sorghum (S. bicolor) and soybean ( $G$. max) grains used for the study were obtained from Oba market in Akure, Ondo State, Nigeria, latitude $10^{\circ} \mathrm{N}$ and $8^{\circ} \mathrm{E}$ longitude. All reagent used in the study were of analytical grade.

\subsection{Sample Preparation}

\subsubsection{Production of Malted Sorghum Flour}

Malting was done according to the method described by [21] with a slight modification as shown in Figure 1. Sorghum grains were sorted to remove foreign matter, soaked for $12 \mathrm{~h}$ in tap water (w/v; 1:2). Soaked grains were drained and sprouted by spreading out on a covered jute bag. Water was sprinkled on it daily until sprouting began. After $24 \mathrm{~h}$ of sprouting, sprouted sorghum was oven dried (Laboratory oven, DHG 9101.1SA) at $65^{\circ} \mathrm{C}$ for $6 \mathrm{~h}$, sprouts were removed on palm by abrasion. The dried malted sorghum

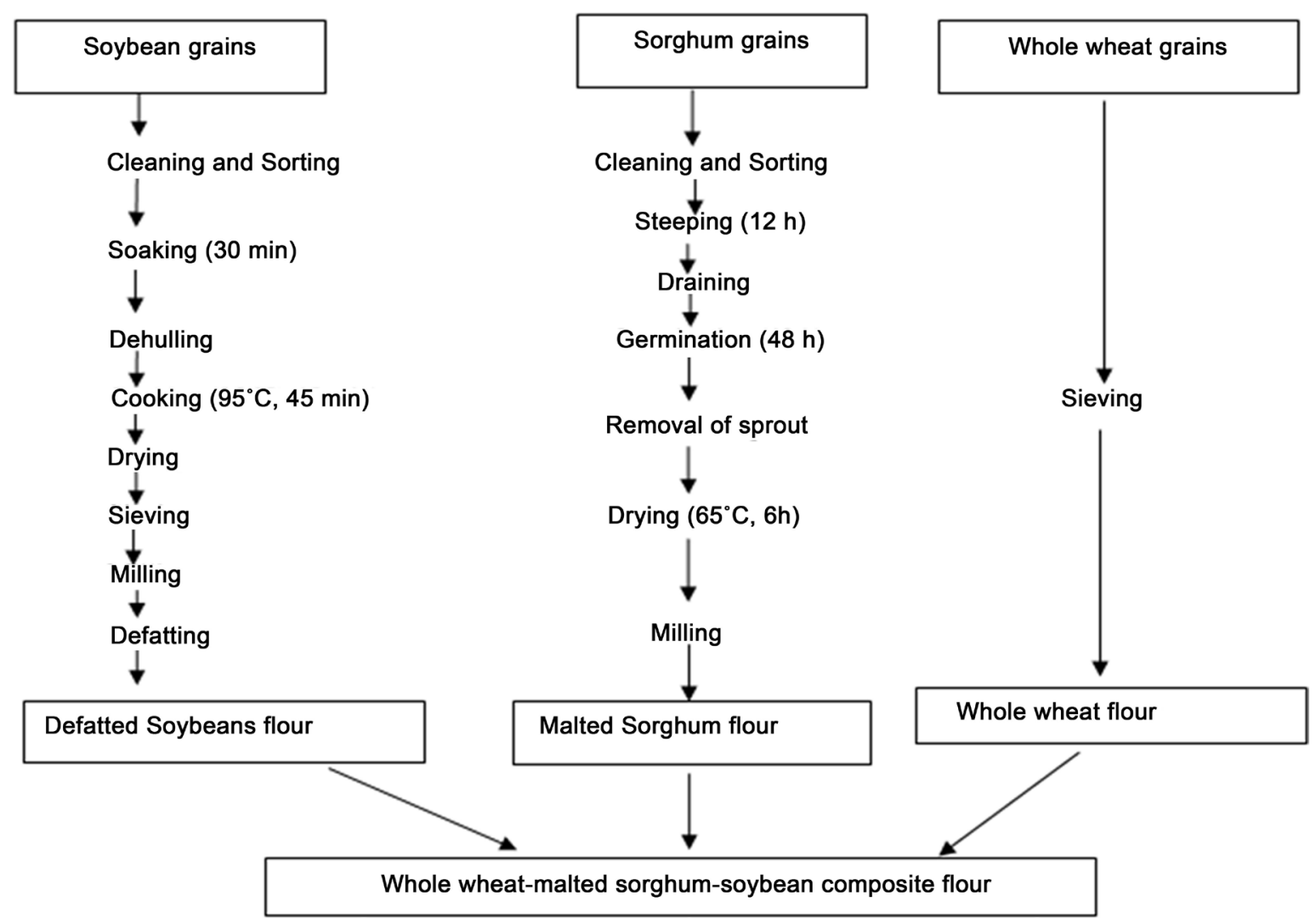

Figure 1. Production of whole wheat-malted sorghum-soybean composite flour. 
was milled into flour using an attrition mill (Atlas exclusive, Alzico Ltd. mill) and sieved through a $250 \mathrm{~mm}$ standard mesh sieve, cooled and packaged for further analysis.

\subsubsection{Production of Defatted Soybean Flour}

Soybean grains were cleaned to remove foreign matter, soaked in water for half an hour, dehulled and cooked for $45 \mathrm{~min}$. Soybean grains were drained and dried in hot air oven (Laboratory oven, DHG 9101.1SA) at $65^{\circ} \mathrm{C}$ for $24 \mathrm{~h}$. The dried grains were milled in an attrition mill (Atlas exclusive, Alzico Ltd. mill) and defatted using soxhlet apparatus. The defatted flour was sieved through a $250 \mathrm{~mm}$ mesh sieve and packaged for further analysis.

\subsection{Physicochemical Properties of Flour Blends}

\section{Determination of Proximate Composition of Flour Blends}

Proximate composition of the blends was carried out using the method described by [22]. Moisture, crude fat, crude ash, crude protein, crude fibre content and carbohydrates were calculated by difference. Water absorption capacity (WAC) and Oil absorption capacity (OAC) were determined using the method described by [23]. Least gelation was determined using the method of [24] while the Swelling capacity was determined using [25]. Pasting characteristics was determined using Rapid ViscoAnalyser. Tannin was determined using [26], Phytate was determined using [27], Total cyanide was determined using [22].

\subsection{Statistical Analysis}

Results were obtained in triplicate and subjected to analysis of variance (ANOVA) and the means were separated by New Duncan's Multiple Range Test (NDMRT) using the Statistical Package for Social Sciences for Windows program version 10.

\section{Results and Discussion}

\subsection{Proximate Composition of Whole Wheat-Malted Sorghum-Soybean Flour}

The proximate composition of the formulated composite flour is presented in Table 1. The protein content ranged from $11.78 \%$ in WSF to $11.98 \%$ in WSS3. Protein content increased with increasing malted sorghum flour substitution. However, there was no significant difference between WSS2 and WSS3 samples. This finding corroborates the observation of [28] on the substitution of flours with malted sorghum flour. Malting leads to the degradation of higher molecular weight storage protein which may contribute to slight increase in protein content in malted products [29]. Crude fibre content increased with increasing substitution with malted sorghum flour. Crude fibre ranged from $1.80 \%-1.98 \%$, crude fibre content was highest in WSS3 (1.98\%).

Crude fibre has been known to promote health as it aids digestion in human. Crude fibre clears buildup of junks in the intestine and regulates bowel movement in humans [30]. Numerous studies have shown that insoluble dietary fibre prevents constipation, increase the mass and volume of feaces, accelerates intestinal peristalsis and has an in- 
Table 1. Proximate composition of whole wheat-malted sorghum-soybean composite flour.

\begin{tabular}{ccccc}
\hline \multirow{2}{*}{ Proximate composition } & \multicolumn{4}{c}{ Samples } \\
\cline { 2 - 5 } & WSF & WSS1 & WSS2 & WSS3 \\
\hline Ash (\%) & $3.48 \pm 0.02^{\mathrm{c}}$ & $3.01 \pm 0.03^{\mathrm{d}}$ & $3.82 \pm 0.01^{\mathrm{b}}$ & $3.96 \pm 0.01^{\mathrm{a}}$ \\
Protein (\%) & $11.78 \pm 0.14^{\mathrm{c}}$ & $11.86 \pm 0.12^{\mathrm{b}}$ & $11.92 \pm 0.10^{\mathrm{a}}$ & $11.98 \pm 0.12^{\mathrm{a}}$ \\
CHO (\%) & $69.09 \pm 0.39^{\mathrm{a}}$ & $67.39 \pm 0.35^{\mathrm{b}}$ & $63.93 \pm 0.18^{\mathrm{c}}$ & $61.77 \pm 0.16^{\mathrm{d}}$ \\
Fat (\%) & $3.15 \pm 0.68^{\mathrm{d}}$ & $4.81 \pm 0.33^{\mathrm{a}}$ & $4.31 \pm 0.09^{\mathrm{b}}$ & $4.14 \pm 0.11^{\mathrm{c}}$ \\
Fibre (\%) & $1.86 \pm 0.01^{\mathrm{b}}$ & $1.80 \pm 0.01^{\mathrm{d}}$ & $1.83 \pm 0.01^{\mathrm{c}}$ & $1.98 \pm 0.00^{\mathrm{d}}$ \\
M.C. (\%) & $1102 \pm 0.17^{\mathrm{d}}$ & $11.13 \pm 0.01^{\mathrm{c}}$ & $11.20 \pm 0.01^{\mathrm{b}}$ & $11.31 \pm 0.01^{\mathrm{a}}$ \\
\hline
\end{tabular}

Values represent mean \pm standard error of triplicate determinations and values with same superscript along the column are not significantly different $(\mathrm{p} \leq 0.05)$. Keys: WSF $=$ Control $(100 \%$ Sorghum Flour $)$, WSS1 $=85 \%$ Wheat Flour $/ 10 \%$ Malted Sorghum Flour/5\% Soybean Flour, WSS2 $=80 \%$ Wheat Flour/15\% Malted Sorghum Flour/5\% Soybean Flour, WSS3 $=75 \%$ Wheat Flour $/ 20 \%$ Malted Sorghum Flour $/ 5 \%$ Soybean Flour, M.C. $=$ Moisture Content, $\mathrm{CHO}=$ Carbohydrate content.

hibitory effect on the development of tumors in the large intestine [31] [32] [33]. Fat content ranged from $3.15 \%-4.81 \%$ and fat content was highest in WSS1. Fat decreased with increased malted sorghum flour substitution. Substitution with malted sorghum flour influences the crude ash content of WSS1 (3.01\%), WSS2 (3.82\%) and WSS3 (3.96\%) compared to the control sample (3.48\%). As the substitution increased, there was significant increase in the ash content of composite flours developed. The ash content obtained was higher than that reported by [34] [35]. Increased ash content implies that samples are rich sources of organic nutrients [36]. Malted sorghum flour could form part of a composite flour with rich minerals content that could be useful in the development of food product that is laden with potentials for the management of micronutrient deficiency.

Moisture content of samples ranged from $11.02 \%$ - $11.31 \%$, it increased with increasing proportion of malted sorghum flour substitution. High moisture content is undesirable in flours. High moisture in foods could enhance the activities of spoilage microorganisms which in turns reduces quality and shelf life of food products. Carbohydrate content ranged from $61.77 \%-69.09 \%$ with the highest value in WSF. There was a decrease in the carbohydrate content as the level of malted sorghum flour substitution increased.

\subsection{Functional Properties of Whole wheat-Malted Sorghum-Soybean Composite Flour}

The functional properties of an agricultural commodity describe its potentials as ingredients in the production of value added food products. These properties are influenced by many factors [37]. The functional properties of whole wheat-malted sorghum-soybean flours are presented in Figure 2. Particle size of a material is inversely related to its bulk density [38].

The packed $(0.86 \pm 0.01 \mathrm{~g} / \mathrm{g})$ and loosed bulked densities $(0.48 \pm 0.00 \mathrm{~g} / \mathrm{g})$ of the composite flours were not significantly different. Low bulk density is desirable in com- 


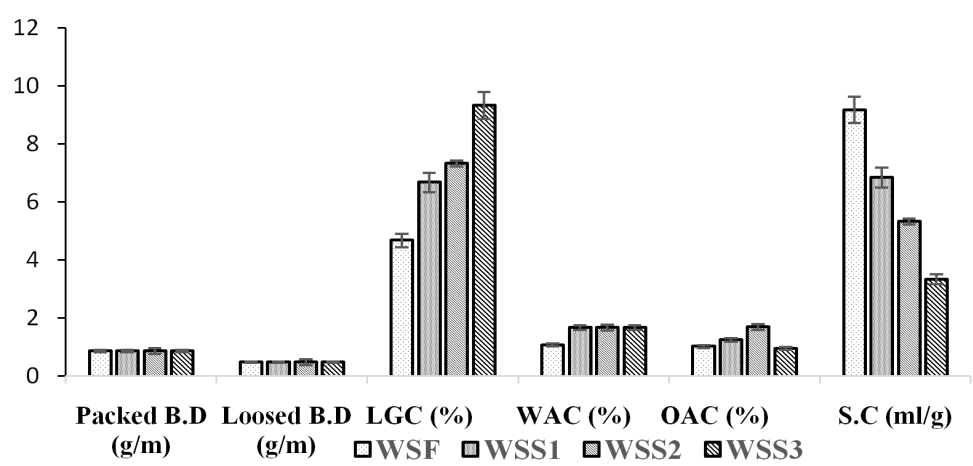

Keys: Packed B.D = Packed Bulk Density, Loosed B.D = Loose Bulk Density, L.G.C = Least Gelation Concentration, WAC $=$ Water Absorption Capacity, OAC $=$ Oil Absorption Capacity, S.C = Swelling Capacity. WSF $=$ Control (100\% Sorghum Flour), WSS1 $=85 \%$ Wheat Flour $/ 10 \%$ Malted Sorghum Flour $/ 5 \%$ Soybean Flour, WSS2 $=80 \%$ Wheat Flour $/ 15 \%$ Malted Sorghum Flour $/ 5 \%$ Soybean Flour, WSS3 $=75 \%$ Wheat Flour $/ 20 \%$ Malted Sorghum Flour/5\% Soybean Flour.

Figure 2. Functional properties of whole wheat-malted sorghum-soybean composite flour.

plementary foods [39] where less quantity is required to meet nutritional requirement of consumers. Also, this could aid easy packing and transportation of food products. The absorption of more water during mixing is a typical characteristic of composite starches [40]. Water absorption capacity of the composite flours was not influenced by increased substitution with malted sorghum flour. There was no significant difference between WSS1, WSS2 and WSS3 however, significant difference exist between the composite flours $(1.67 \pm 14.43 \mathrm{~g} / \mathrm{ml})$ and control $(1.07 \pm 28.87 \mathrm{~g} / \mathrm{ml})$. [41] reported that water absorption capacity of maize was influenced by processing especially treatment that could have effects on starch gelatinization. The low WAC in this study could be due to the fact that malting does not influence starch gelatinisation. Lipid rich flour could results in the decrease of water absorption capacity due to the fact that lipids blocks the polar sites of proteins thus attenuating the absorption of water [23]. The water absorption capacity is indicative of the amount of water required to develop dough consistency which makes the dough to rise when gluten is fully developed. The oil absorption capacity (OAC) of samples ranged from $0.95 \%-1.68 \%$. OAC was highest in WSS2. Least gelation concentration (LGC) of the composites flours ranged from $6.67 \%$ - 9.33\%. LGC was highest in WSS3 (9.33\%) while WSF (4.67\%) was lowest. The LGC of composite flours increased with increasing substitution with malted sorghum flour. Samples showed less ability to form gel easily. Variation in gelling properties of flours could be attributed to differences in constituents and denatured molecules of globulin in flour samples [42]. Swelling capacity of the composite flour decreased with increasing substitution with malted sorghum flour. Low swelling capacity of the composite flours may be due to processing (malting) which could result in the breakdown of starch components-amylose and non-reducing sugar.

\subsection{Anti-nutritional Composition of Whole Wheat-Malted Sorghum-Soybean Composite Flours}

The antinutritional content of whole wheat-malted sorghum-soybean composite flours 
is presented in Table 2. Phytate of composite flours ranged from $1.14-1.9 \mathrm{mg} / \mathrm{g}$, Oxalate $(1.64-3.01 \mathrm{mg} / \mathrm{g})$, Cyanide $(2.02-5.45 \mathrm{mg} / \mathrm{g})$ while Tannin $(0.03 \mathrm{mg} / \mathrm{g})$ was not significantly different. Phytate contents of WSS1 (1.51 mg/g), WSS2 (1.74 mg) and WSS3 $(1.90 \mathrm{mg})$ were significantly different from the control $(1.57 \mathrm{mg} / \mathrm{g})$ at $(\mathrm{P} \leq 0.05)$. Phytate content of composites flour increased with increased substitution with malted sorghum. Phytic acid binds trace elements and macro-elements such as zinc, calcium, magnesium and iron making dietary minerals unavailable for absorption and utilisation by the body [43] [44]. Tannin content of samples was not affected by degree of substitution with malted sorghum. Malting was ineffective in degrading antinutrient like phytate, oxalate and cyanide in sorghum. However, phytate, tannin and oxalate contents were within the acceptable limit $(80 \mathrm{mg} / \mathrm{g})$ that is detrimental to health [45]. Tannins are capable of forming insoluble complexes with proteins which in turn reduce protein digestibility [46] as a result of inactivation of digestive enzymes and interaction of protein substrate with ionisable iron [47]. The cyanide content obtained for all the samples were lower than the recommended safe level of $10 \mathrm{mg} \mathrm{HCN} / \mathrm{kg}$ [48] [49] [50] reported that soaking significantly reduces total cyanide content in fresh roots. A similar trend was observed in the malted sorghum flour. This reduction in cyanide content could be due to the preliminary soaking of the grains prior to malting.

\subsection{Pasting Properties of Whole Wheat-Malted Sorghum-Soybean Flour}

The pasting characteristics of whole wheat-malted sorghum-soybean composite flour are presented in Table 3 . The peak viscosity is the maximum viscosity developed during or soon after the heating stage in the determination. According to [51] the maximum viscosity of starch suspension heated in an excess of water occur after most granule swelling had ceased resulting in increased viscosity. Higher swelling index is indicative of high peak viscosity while higher solubility is indicative of starch degradation resulting in reduced paste viscosity [52]. The peak viscosity reduced with increasing substitution of malted sorghum flour. The composite flours were significantly different from the control except WSS3. The increase in the peak viscosity of composite flours could be due to addition of malted sorghum flour which has undergone breakdown of starches during the malting process.

Table 2. Anti-nutritional content of whole wheat-malted sorghum-soybean composite flours.

\begin{tabular}{ccccc}
\hline \multirow{2}{*}{ Sample } & \multicolumn{4}{c}{ Antinutrients composition } \\
\cline { 2 - 5 } & Phytate $(\mathrm{mg} / \mathrm{g})$ & Oxalate $(\mathrm{mg} / \mathrm{g})$ & Tannin $(\mathrm{mg} / \mathrm{g})$ & Cyanide $(\mathrm{mg} / \mathrm{g})$ \\
\hline WSF & $1.57 \pm 0.49^{\mathrm{d}}$ & $1.16 \pm 0.05^{\mathrm{d}}$ & $0.03 \pm 0.01^{\mathrm{a}}$ & $1.38 \pm 0.01^{\mathrm{d}}$ \\
WSS1 & $1.51 \pm 0.00^{\mathrm{c}}$ & $1.64 \pm 0.00^{\mathrm{c}}$ & $0.03 \pm 0.00^{\mathrm{a}}$ & $2.02 \pm 0.00^{\mathrm{c}}$ \\
WSS2 & $1.74 \pm 0.00^{\mathrm{b}}$ & $2.16 \pm 0.00^{\mathrm{b}}$ & $0.03 \pm 0.00^{\mathrm{a}}$ & $4.05 \pm 0.00^{\mathrm{b}}$ \\
WSS3 & $1.9 \pm 0.00^{\mathrm{a}}$ & $3.01 \pm 0.05^{\mathrm{a}}$ & $0.03 \pm 0.00^{\mathrm{a}}$ & $5.45 \pm 0.00^{\mathrm{a}}$ \\
\hline
\end{tabular}

Values represent mean \pm standard error of triplicate determinations and values with same superscript along the column are not significantly different $(\mathrm{p} \leq 0.05)$. Keys: WSF $=$ Control $(100 \%$ Sorghum Flour), WSS $1=85 \%$ Wheat Flour $/ 10 \%$ Malted Sorghum Flour $/ 5 \%$ Soybean Flour, WSS2 $=80 \%$ Wheat Flour/15\% Malted Sorghum Flour $/ 5 \%$ Soybean Flour, WSS3 $=75 \%$ Wheat Flour $/ 20 \%$ Malted Sorghum Flour $/ 5 \%$ Soybean Flour. 
Table 3. Pasting properties of whole wheat-malted sorghum-soybean composite flours.

\begin{tabular}{ccccc}
\hline \multirow{2}{*}{ Sample } & \multicolumn{4}{c}{ Pasting characteristics } \\
\cline { 2 - 4 } & WSF & WSS1 & WSS2 & WSS3 \\
\hline Peak Viscosity (RVU) & $298.82^{\mathrm{c}}$ & $434.92^{\mathrm{a}}$ & $316.92^{\mathrm{b}}$ & $281.00^{\mathrm{c}}$ \\
Holding Strength (RVU) & $168.41^{\mathrm{c}}$ & $213.25^{\mathrm{a}}$ & $187.50^{\mathrm{a}}$ & $168.41^{\mathrm{c}}$ \\
Breakdown Viscosity (RVU) & $22.06^{\mathrm{a}}$ & $130.29^{\mathrm{b}}$ & $221.09^{\mathrm{a}}$ & $59.25^{\mathrm{c}}$ \\
Final Viscosity (RVU) & $243.00^{\mathrm{d}}$ & $263.83^{\mathrm{b}}$ & $253.67^{\mathrm{c}}$ & $297.50^{\mathrm{a}}$ \\
Setback Viscosity (RVU) & $34.83^{\mathrm{d}}$ & $50.55^{\mathrm{c}}$ & $66.41^{\mathrm{b}}$ & $75.00^{\mathrm{a}}$ \\
Pasting Temp. ( $\left.{ }^{\circ} \mathrm{C}\right)$ & $72.77^{\mathrm{b}}$ & $75.25^{\mathrm{b}}$ & $80.22^{\mathrm{a}}$ & $80.49^{\mathrm{a}}$ \\
Peak Time (min) & $4.10^{\mathrm{d}}$ & $4.55^{\mathrm{c}}$ & $2.09^{\mathrm{b}}$ & $5.46^{\mathrm{a}}$
\end{tabular}

Values represent mean \pm standard error of triplicate determinations and values with same superscript along the column are not significantly different $(\mathrm{p} \leq 0.05)$. Keys: WSF $=$ Control $(100 \%$ Sorghum Flour), WSS $1=85 \%$ Wheat Flour $/ 10 \%$ Malted Sorghum Flour $/ 5 \%$ Soybean Flour, WSS2 $=80 \%$ Wheat Flour $/ 15 \%$ Malted Sorghum Flour $/ 5 \%$ Soybean Flour, WSS3 $=75 \%$ Wheat Flour $/ 20 \%$ Malted Sorghum Flour $/ 5 \%$ Soybean Flour.

The holding strength of composite flour is the minimum viscosity after the peak is reached [53]. The highest holding strength was obtained in WSS1 (213.25 RVU) and lowest in WSF and WSS3 (168.41 RVU). Holding strength of composites flours decreased with increasing substitution with malted sorghum flour. This findings corroborate that of [51] on breadfruit flour. Breakdown viscosity increased with malted sorghum flour substitution up to $15 \%$. Breakdown viscosity in WSF, WSS1 and WSS2 were 221.06 RVU, 130.29 and 129.66 RVU respectively. WSS3 had the lowest (59.29 RVU) breakdown viscosity implying high paste stability. The smaller the breakdown viscosity, the higher the paste stability [51]. Formation of gel is indicative of increase viscosity. Final viscosity of the composite flours increased with increased substitution with malted sorghum flour. WSS3 composite flour formed better gel than other samples. The setback viscosity was highest in WSS3 (75.00 RVA) and lowest in WSF (34.83 RVA). Setback value of composite flours increased with increasing substitution with malted sorghum flour. Setback is the phase of the pasting curve after cooling to $50^{\circ} \mathrm{C}$. Setback shows the tendency of starches to re-associate, retrograde or re-order its molecules [51]. High setback is associated with syneresis, or weeping. The peak time of the composite flour blends increased with an increase in the degree of substitution of malted sorghum flour. The pasting temperature of WSF and WSS1 WSS2, WSS3 were not significantly different $(\mathrm{P} \leq 0.05)$.

\section{Conclusion}

In a time as this, when malnutrition and food insecurity is prevailing in many parts of the world efforts to improve the economic importance of indigenous crops by value addition through composite, flour production should be given a priority. Outcomes from this study inferred that Malted sorghum can be utilised in the production of value-added products like confectionaries. Malted sorghum flour substitution might not affect the water absorption capacity of composite flours. Malting could be ineffective in 
the degradation of antinutrients in sorghum grains. Substitution of flours with malted sorghum can best be done at $20 \%$ degree of substitution. WSS3 could be adapted to product requiring high level of paste viscosity and stability. Malting of sorghum can improve the nutritional quality of flours that can be used in confectionary industries. Further studies on its protein and starch digestibility and mineral bioavailability using both in vitro and in vivo studies should be done prior to its use in confectionary products.

\section{References}

[1] Sanni, L.O., Christiana, A.B. and Silifat, A.S. (2004) Production of Instant Cassava Noodles. Journal of Food Technology, 2, 83-89.

[2] Seibel, W. (2006) Composite Flours. In: Popper, L., Ed., Future of Flour. A Compendium of Flour Improvement, VerlagAgriMedia, Hamburg, 193-198.

[3] Bugusu, B.A., Campanella, O. and Hamaker, B.R. (2001) Improvement of Sorghum-Wheat Composite Dough Rheological Properties and Bread Making Quality through Zein Addition. Cereal Chemistry, 78, 31-35. http://dx.doi.org/10.1094/CCHEM.2001.78.1.31

[4] Oluwole, O.B. and Karim, O.R. (2005) Production of Biscuits from Bambara, Cassava and Wheat Flour Blends. Journal of Raw Material Research, 2, 34-38.

[5] Okoli, E.V., Okolo, B.N., Moneke A.N. and Ire, F.S. (2010) Effects of Cultivar and Germination Time on Amylolytic Potential, Extract Yield and Wort Fermenting Properties of Malting Sorghum. Asian Journal of Biotechnology, 2, 14-26. http://dx.doi.org/10.3923/ajbkr.2010.14.26

[6] Elemo, G.N., Elemo, B.O. and Okafor, J.N.C. (2011) Preparation and Nutritional Composition of a Weaning Food Formulated from Germinated Sorghum (Sorghum bicolor) and Steamed Cooked Cowpea (Vignaunguiculata Walp.). American Journal of Food Technology, 6, 413-421. http://dx.doi.org/10.3923/ajft.2011.413.421

[7] Mohammed, M.A.E., Makki, H.M.M. and Mustafa, A.E.M.I. (2011) Production of Cereal-Based Infant Food from Sorghum [Sorghum bicolor (L) Moench] and Pigeon Pea (Cajanuscajan). Pakistan Journal of Nutrition, 10, 910-913. http://dx.doi.org/10.3923/pjn.2011.910.913

[8] Khattab, R.Y. and Arntfield, S.D. (2009) Nutritional Quality of Legume Seeds As Affected by Some Physical Treatments. 2. Antinutritional Factors. LWT-Food Science and Technology, 42, 1113-1118. http://dx.doi.org/10.1016/j.lwt.2009.02.004

[9] Singh, U., Klierdekar, M.S. and Jambunathan, R. (1982) Studies on Desiand Kabuli Chick Peas Cultivar: The Level of Amylase Inhibitors. Level of Oligosaccharides and In Vitro Digestibility. Journal of Food Science, 47, 510-512. http://dx.doi.org/10.1111/j.1365-2621.1982.tb10113.x

[10] Alabi, M.O. and Oluwatosin, B.C. (2001) Creating Awareness on Utilization of Soybean Flour for Baked Products in the Catering Industry; A Preliminary Study of Physical Properties and Acceptability of Soy Cake. African Journal of Biotechnology, 7, 2623-2625.

[11] Ampofo, V. (2009) Production and Sensory Analysis of Soybean and Wheat Flour Composite Cake. HND Dissertation, Cape Coast Polytechnic, Cape Coast, Ghana.

[12] Pamplona, R. (2005) Encyclopedia of Food and Their Healing Power Properties of WheatPlantain Composite Flours. African Journal of Food Nutrition, 7, 1-22.

[13] Hugo, L.F., Rooney, L.W. and Taylor, J.R.N. (2000) Malted Sorghum as a Functional Ingredient in Composite Bread. Cereal Chemistry Journal, 77, 428-432. 
http://dx.doi.org/10.1094/CCHEM.2000.77.4.428

[14] Mepba, H.D., Eboh, L. and Nwaojigwa, S.U. (2008) Chemical Composition, Functional and Baking Properties of Wheat-Plantain Composite Flours. African Journal of Food Nutrition, 7, 1-22.

[15] Spiekermann, U. (2006) Brown Bread for Victory: German and British Whole Meal Politics in the Interwar Period. In: Trentmann, F. and Just, F., Eds., Food and Conflict in Europe in the Age of the Two World Wars, Palgrave Macmillan UK, Basmastoke/New York, 143-171. http://dx.doi.org/10.1057/9780230597495 7

[16] Food and Agricultural Organisation (FAO) (2006) Food and Agriculture Bulletin on Food Security. www.fao.org/docrep/x5030E/X15032E06.htm

[17] Ekop, A.S., Lessien, E.A. and Abasiekong, B.O. (2007) Industrial Potentials of Cocoyam for Bread Foods. Human Nutrition, 54, 123-266.

[18] Lin, L., Liu, H., Lin, S. and Mau, J. (2009) Quality and Antioxidant Property of Buckwheat Enhanced Wheat Bread. Journal of Food Chemistry, 37, 461-467. http://dx.doi.org/10.1016/j.foodchem.2008.07.022

[19] Ade-Omowaye, B.I., Bolarinwa, B.A. and Adebiyi, A.O. (2008) Evaluation of Tigernut ( $C y$ perusesculentus) - Wheat Composite Flour and Bread. African Journal of Food Science, 2, 87-89.

[20] Eggleston, G., Omoka, P.E. and Arowoshegbe, A.U. (1992) Flour, Starch and Alternative (Wheatless) Bread Making Quality of Various Cassava Clones. Journal of Science and Food Agriculture, 62, 61-66. http://dx.doi.org/10.1002/jsfa.2740620108

[21] IITA (1990) Cereal in Tropical Africa. A Reference Manual, International Institute of Tropical Agriculture, Ibadan, Nigeria, 7-8.

[22] Association of Official Analytical Chemists (AOAC) (2005) Official Methods of Analysis of the AOAC. 16th Edition, Washington DC, 1298 p.

[23] Sathe, S.K. and Salunkhe, D.K. (1981) Functional Properties of Great Northen Bean (PaeoIus vulgaris L.) Protein: Emulsification Foaming, Viscocity and Gelation Properties. Journal of Food Science, 46, 71-81. http://dx.doi.org/10.1111/j.1365-2621.1981.tb14533.x

[24] Coffman, A.W. and Gracia, V.V. (1977) Functional Properties and Amino Acid Contents of Protein Isolate from Mung Bean Flour. Journal of Food Technology, 12, 473-484. http://dx.doi.org/10.1111/j.1365-2621.1977.tb00132.x

[25] Ukpabi, U.J. and Ndimele, C. (1990) Evaluation of Gari Production in Imo State Nigeria. Nigeria Food Journal, 8, 105-110.

[26] Makkar, H.P.S., Blummel, M., Borowy, N.K. and Becker, K. (1993) Gravimetric Determination of Tannins and Their Correlations with Chemical and Protein Precipitation Methods. Journal of Food Science Agriculture, 61, 161-165. http://dx.doi.org/10.1002/jsfa.2740610205

[27] Young, J. (2001) Functional Bakery Products: Current Directions and Future Opportunities. Food Industrial Journal, 4, 136-144.

[28] Ariahu, C.C., Ukpabi, U. and Mbajunwa, K.O. (1999) Production of African Breadfruit (Treculia africana) and Soybean (Glycine max) Seed Based Food Formulations, 1: Effects of Germination and Fermentation on Nutritional and Organoleptic Quality. Plant Foods for Human Nutrition, 54, 193-206. http://dx.doi.org/10.1023/A:1008153620287

[29] Wu, H.M. (1983) Production and Textural Properties of Soy-Cheese Whey Curd. Journal of Food Science, 48, 1562-1563. http://dx.doi.org/10.1111/j.1365-2621.1983.tb03540.x

[30] Sobota, A., Sykut-Domańska, E. and Rzedzicki, Z. (2010) Effect of Extrusion-Cooking Process on the Chemical Composition of Corn-Wheat Extrudates, with Particular Emphasis 
on Dietary Fibre Fractions. Polish Journal of Food and Nutrition Sciences, 60, 251-259.

[31] Srikumar, T.S. (2000) Effects of Consumption of White Bread and Brown Bread on the Concentrations of Fecal Bile Acids and Neutral Steroids and on Fecal Enzyme Activities. Nutrition Research, 20, 327-333. http://dx.doi.org/10.1016/S0271-5317(00)00126-3

[32] Kritchevsky, D. (2001) Dietary Fiber in Health and Disease. In: McCleary, B. and Prosky, L., Eds., Advanced Dietary Fiber Technology, Blackwell Science Ltd., London, 149-161.

[33] Bingham, S. (2004) Epidemiology of Dietary Fiber and Colorectal Cancer. In: Van der Kamp, J.W., Asp, N.-G., Miller Jones, J. and Schaafsma, G., Eds., Dietary Fiber-Bioactive Carbohydrates for Food and Feed, Academic Publishers, Wageningen, 179-182.

[34] Osundahunsi, O.F. and Aworh, O.C. (2003) Nutritional Evaluation, with Emphasis on Protein Quality, of Maize Based Complementary Foods Enriched with Soya Bean and Cowpea Tempe. International Journal of Food Science \& Technology, 38, 809-813. http://dx.doi.org/10.1046/j.1365-2621.2003.00736.x

[35] Ikya, J.K., Gernah, D.I. and Sengev, I.A. (2013) Proximate Composition, Nutritive and Sensory Properties of Fermented Maize, and Full Fat Soy Flour Blends for “Agidi” Production. African Journal of Food Science, 7, 446-450. http://dx.doi.org/10.5897/AJFS09.224

[36] Ndife, J., Obiegbunna, J. and Ajayi, S. (2013) Comparative Evaluation of the Nutritional and Sensory Quality of Major Commercial Whole-Wheat Breads In Nigerian Market. Advance Journal of Food Science and Technology, 5, 1600-1605.

[37] Womeni, H.M., Tiencheu, B., Linder, M., Nabayo, E.M.C., Tenyang, N., Mbiapo, F.T., Villeneuve, P., Fanni, J. and Parmentier, M. (2012) Nutritional Value and Effect of Cooking, Drying and Storage Process on Some Functional Properties of Rhynchophorus phoenicis. International Journal of Life Science and Pharma Research, 2, 203-219.

[38] Akubor, P.I., Yusuf, D. and Obiegunam, J.E. (2013) Proximate Composition and Some Functional Properties of Flour from the Kernel of African Star Apple (Chrysophyllual albidum). International Journal of Agricultural Policy and Research, 1, 062-066.

[39] Akpata, M.I. and Akubor, P.I. (1999) Chemical Composition and Selected Functional Properties of Sweet Orange (Citrus sinensis) Seed Flour. Plant Foods for Human Nutrition 54, 353-362. http://dx.doi.org/10.1023/A:1008153228280

[40] Doxastakis, G., Zafiriadis, I., Irakil, M., Marlani, H. and Tananaki, C. (2002) Lupin, Soya and Triticale Addition to Wheat Flour Dough and Their Effect on Rheological Properties. Food Chemistry, 77, 219-227. http://dx.doi.org/10.1016/S0308-8146(01)00362-4

[41] Okaka, J.C. and Potter, N.N. (1979) Physicochemical and Functional Properties of Cowpea Powders Processed to Reduce Beany Flavour. Journal of Food Science, 44, 1235-1240. http://dx.doi.org/10.1111/j.1365-2621.1979.tb03488.x

[42] Sathe, S.K., Deshpande, S.S. and Salunkhe, D.K. (1982) Functional Properties of Lupin Seed (Lupirinus nutabilis) Proteins and Protein Concentrates. Journal of Food Science, 47, 491497. http://dx.doi.org/10.1111/j.1365-2621.1982.tb10110.x

[43] Sandberg, S.A. (2002) Bioavailability of Minerals in Legumes. British Journal of Nutrition, 88, 281-285. http://dx.doi.org/10.1079/BJN/2002718

[44] Melaku, U., West, C.E. and Habtamu, F. (2005) Content of Zinc, Iron, Calcium and Their Absorption Inhibitors in Foods Commonly Consumed in Ethiopia. Journal of Food Composition and Analysis, 18, 803-817. http://dx.doi.org/10.1016/j.jfca.2004.09.008

[45] Morad, M.M., Doherty, C.A. and Rooney, L.W. (1984) Effect of Sorghum Variety on Baking Properties of US Conventional Bread, Egyptian Pita Balady Bread and Cookies. Journal of Food Science, 49, 1070-1074. http://dx.doi.org/10.1111/j.1365-2621.1984.tb10394.x

[46] Ogunlade, I., Ilugbiyin, A. and Osasona, A.I. (2011) A Comparative Study of Proximate 
Composition, Antinutrient Composition and Functional Properties of Pachira glabra and Afzelia africana Seed Flours. African Journal of Food Science, 5, 32-35.

[47] Ogunkoya, M.O., Abulude, F.O. and Oni, A.B. (2006) Determination of Anatomical, Proximate, Minerals, Oxalate, Tannin and Phytate Compositions of Cuban Boa (Epicrates anquifer). Electronic Journal of Environmental, Agricultural and Food Chemistry, 5, 1160 1166.

[48] FAO/WHO (1991) Joint FAO/WHO Food Standards Programme. Codex Alimentarius Commission XII (Suppl. 4), FAO, Rome.

[49] Bandna, C. (2012) Effect of Processing on the Cyanide Content of Cassava Products in Fiji. Journal of Microbiology, Biotechnology and Food Sciences, 2, 947-958.

[50] Hongbété, F., Mestres, C., Akissoé, N. and Nago, M.C. (2009) Effect of Processing Conditions on Cyanide Content and Colour of Cassava Flours from West Africa. African Journal of Food Science, 3, 001-006.

[51] Akanbi, C.T., Nazamid, S. and Adebowale, A.A. (2009) Functional and Pasting Properties of a Tropical Breadfriuit (Artocarpus altilis) Starch from Ile-Ife, Osun State, Nigeria. International Food Research Journal, 16, 151-157.

[52] Oluwalana, I.B., Oluwamukomi, M.O., Fagbemi, T.N. and Oluwafemi, G.I. (2011) Effects of Temperature and Period of Blanching on the Pasting and Functional Properties of Plantain (Musa parasidiaca) Flour. Journal of Stored Products and Postharvest Research, 2, 164-169.

[53] Bakare, H.A. (2008) Evaluation Rheological Properties and Baking Performance of Wheat Composite Flour Produced from Lye Peeled Breadfruit (Artocarpus comunis) and Cassava. Unpublished $\mathrm{PhD}$ Thesis, University of Ibadan, Ibadan.

Submit or recommend next manuscript to SCIRP and we will provide best service for you:

Accepting pre-submission inquiries through Email, Facebook, LinkedIn, Twitter, etc.

A wide selection of journals (inclusive of 9 subjects, more than 200 journals)

Providing 24-hour high-quality service

User-friendly online submission system

Fair and swift peer-review system

Efficient typesetting and proofreading procedure

Display of the result of downloads and visits, as well as the number of cited articles

Maximum dissemination of your research work

Submit your manuscript at: http://papersubmission.scirp.org/

Or contact fns@scirp.org 